The section on chromosome organization, for example, begins with an article by Ris; Britten, MeCarthy and Walker and his colleagues all have their say on satellite DNAs and the evolution of DNA base sequences; Bernhard writes on the ultrastructure of cancer cells, Callan on lampbrush chromosomes, Afzelius on cilia and flagella, Bennett on the cell surface, Robertson on the structure of membranes, and so on through the list of fifty-three contributors. The organization of the book is equally familiar. It starts with a section on the evolution of DNA and then progresses first to the organization of viral, bacterial and eukaryotic chromosomes, followed by the structure and bichemistry of the interphase and dividing nucleus, and ends up with the cavalcade of the cell organelles. I admit the volume is not entirely without surprises. The editor deserves to be congratulated, for example, for deciding to include articles on abnormalities of sex chromosomes and autosomal ehromosomes, and for persuading Hamerton and Taylor, both from the Paediatric Unit at Guy's Hospital, to write them.

Books of this sort are always out of date before they are published; in this case, as far as I can sce, the most recent references date from early 1968. And inevitably it is incomplete; somatic cell geneties, tumour virology and the work stemming from Watkins and Harris's diseovery of virus mediated cell fusion are all topies one might expect to find discussed but they are barely mentioned.

The blurb talks of the handbook being the result of "the pressing need for a deeper understanding of the molecular interactions within cells" and of our being close to the threshold of some great synthesis that will provide an all-embracing view of the cell. The need for a deeper understanding of cells is obvious, but I doubt if this book will help much in bringing it about. Of course it contains many useful pieces of information but they are far from being in that particularly accossible form one expects of something parading as a handbook. Accossibility of information is precisely what has made the Chemical Rubber Handbooks so successful and useful. The Handbook of Molecular Cytology is not in the same category in spite of its title, and purchasers, even libraries, have a right to expect a great deal more than this tome offers if they are being charged £28.

JoHN TOOzE

\section{NUCLEAR REACTIONS}

\section{Nuclear Reactions}

By I. E. McCarthy. (The Commonwealth and International Library of Science, Technology, Engineering and Liberal Studies : Selected Readings in Physics.) Pp. viii +327. (Pergamon: Oxford, London and New York, February 1970.) 45s (\$7) boards; $35 s(\$ 5.50)$ flexi-cover.

THIs book is designed to introduce the theory of nuclear reactions to undergraduate students after a first course in quantum mechanies. The first part of the book contains a 100-page review of the theory of scattering and reactions, and is followed in the second part by a selection of original papers published between 1929 and 1965 .

The introductory review covers the elements of scattering theory, the theory of the compound nucleus, the optical model, a discussion of nuclear structure and nuclear forces, and a discussion of direct reactions. 'The wide range of subjects and the condensed form in which they are described seem to make this section far too difficult for undergraduates. For example, the basic scattering theory, including the definitions of differential cross-section, partial wave expansion, resonance and the like, is presented without any diagrams at all, the physical significance of the asymptotic form of the wave-function is not discussed, and such terms as phase shift and channel radius are not explained. Later on, the description of compound nucleus theory is much more advaneed than that usually given in undergraduate texts, and the discussion of nuclear structure includes the Bethe-Goldstone equation and the non-local K-matrix. It is doubtful whether this part of the book would be of any value to postgraduates, because those who are specializing in nuclcar reactions would need a more detailed treatment of the subject and those who are reading for general interest would find the explanation of the physics rather inadequate.

The choice of original papers by Rutherford, Mott, Bohr and Serber seems ver appropriate, but the other papers chosen are much too demanding for undergraduates. While one can agreo with the publisher's contention that undergraduates should not only learn from textbooks but should make aequaintance with the original literature, it will be chcaper and more profitable in this case to send the students to the library.

DAPHNE F. JACKSON

\section{BUBBLE CHAMBERS}

\section{Cloud and Bubble Chambers}

By C. Henderson. (Methuen's Monographs on Physical Subjects.) Pp. vii $+118+4$ plates. (Methuen: London, January 1970.) $38 s$.

THE title of this book is not altogether appropriate: it is largely about bubble chambers, their application to accelerator physics and the processing and analysis of bubble chamber photographs. References to cloud chambors are not in comparable detail, are uneven and are on the whole slanted to their possible application in the same area: the discussion of cloud chambers provides no guidance at all to the sort of problems recently set by possible "quark" tracks from Sydney! The author is probably not as at home in the cloud chamber literature as in that of bubble chambers: for cxample, diffusion chambers of the Langsdorf type were first described in 1936, not 1939. If, as is probably intended, the cloud chamber material is provided for purposes of comparison of the nuclcation process and principally as a background to bubble chamber technology, it would have been valuable to give also comparable data and discussion on the scope and usefulness of nuclear emulsions and the problems of track measurcments in them, and perhaps a brief if wider survey of the wholc ficld of application of "visual track" detectors of all kinds.

Subject to these reservations, which are really substantial only as regards the title, this is an excellent book which provides a concise, well written and readable back. ground to the technology of bubble chambers used with large particle accelerators. It brings out clearly the problems of construction of the chambers themselves and of expansion systems, and the varying conditions and purposes for which different liquid fillings are suitable. The differences in bubble development in various liquids are troated admirably, and for the non-expert reader the very different optical problems in hydrogen and in heavy liquid chambers, and some of the elegant solutions of these problems, are some of the unexpected features which emphasize the practical approach in a very woll balanced monograph.

Tho book gains from exceptionally well chosen and reproduced photographs, which are set out with excellent descriptive material. It should appeal to a very wide range of readers.

J. G. WILSON

\section{ANALYSIS WITH ENZYMES}

\section{Enzymatic Methods of Analysis}

By Gcorge G. Guilbault. (International Series of Monographs in Analytical Chemistry, Vol. 34.) Pp. xv +347. (Pergamon: Oxford, London and New York, January 1970.) $75 s ; \$ 10$.

THIs book, which contains a relatively brief survey of some aspects of the use of enzymos in analytical chemistry, 